\title{
Analisis Kegagalan Pada Roda Gigi Miring Intermediate Gear 2 Pada Gear Box Untuk Roller Press Milling Machine
}

\author{
Andri Anto, Dedison Gasni \\ Jurusan Teknik Mesin, Fakultas Teknik, Universitas Andalas, Padang
}

INFORMASI ARTIKEL

Sejarah Artikel:

Diterima Redaksi: 04 Agustus 2017

Revisi Akhir: 01 September 2017

Diterbitkan: 31 Oktober 2017

\section{KATA KUNCI}

Helical gear

Helical gear failure

Failure analysis

Fatigue failure

Contact mechanics

KORESPONDENSI

E-mail: andrianto313.aa@gmail.com

\section{PENDAHULUAN}

Gear box berfungsi untuk mentransmisikan daya dengan mengubah torsi dan kecepatan putaran yang dihasilkan motor penggerak ke Roller Press. Roller Press berfungsi untuk memperkecil ukuran material batu kapur pada industri semen agar proses milling menjadi lebih cepat jika dibandingkan dengan material batu kapur yang tidak melalui proses Roller Press. Gear box memiliki empat roda gigi miring penghantar dimana masing-masing roda gigi berbeda karakteristiknya, baik jumlah gigi maupun diameternya. Dari keempat roda gigi tersebut, dua buah roda gigi miring Intermediate Gear 2 telah mengalami kegagalan, dimana posisi kedua roda gigi tersebut dapat dilihat pada Gambar 1. Akibat kegagalan roda gigi miring pada gear box Roller Press tersebut mengakibatkan terhentinya proses milling. Hal ini akan mengakibatkan kerugian yang besar bagi perusahaan akibat berhentinya pengoperasian Roller Press ini. Agar kejadian ini tidak terulang lagi dimasa yang akan datang, perlu dilakukan analisis penyebab kegagalan dari roda gigi miring dengan mengetahui akar penyebab (root cause) kegagalan pada roda gigi tersebut dan 
diharapkan untuk masa yang akan datang kegagalan seperti ini tidak terulang lagi.

Dari riwayat pemakaian gear box dari Roller Press ini, menunjukkan bahwa gear box telah dipasang selama \pm 17 tahun dan telah mengalami dua kali pergantian roda gigi. Kegagalan pada roda gigi miring intermediate gear pada gear box ini terjadi secara tiba-tiba yang ditandai dengan adanya suara kasar pada gear box. Dari hasil wawancara dilapangan didapat informasi, bahwa maintenance pada gear box Roller Press ini telah dilakuan secara berkala terutama dalam penggantian cairan pelumas, sedangkan data vibrasi tidak diperoleh karena tidak dilakukan pengukuran. Dari hasil pengamatan di lapangan menunjukkan bahwa kegagalan yang terjadi pada gear box berupa patahnya gigi pada roda gigi intermediate gear 2 .

Penyebab kegagalan roda gigi dapat disebabkan oleh beberapa hal diantaranya: kesalahan desain, ketidak tepatan pemakaian, dan kesalahan dalam pembuatan atau manufacturing. Kesalahan desain dapat disebabkan oleh beberapa hal diantaranya adalah: ketidaksesuaian dari geometri dari roda gigi, ketidaksesuaian material, kualitas material yang jelek, ketidaktepatan sistem pelumas dll. Ketidaktepatan dalam pemakaian diantarnya; ketidaksesuaian pemasangan dan instalasi, pelumasan yang jelek, dan pemeliharaan (maintenance) yang jelek. Kesalahan dalam pembuatan (manufacturing) dapat berupa proses machining yang jelek atau kesalahan dalam proses perlakukan panas [1].

Surface pitting merupakan salah satu modus utama kegagalan dari komponen mesin yang dikenai beban rolling kontak, seperti roda gigi dan bantalan, dan dinyatakan dengan service life dari komponen tersebut [2]. Proses fatigue pada permukaan yang berkontak dimulai dengan terbentuknya micro pitting diikuti dengan pertumbuhan retak yang dikenal dengan crak initiation dan selanjutnya terjadi pelepasan dari lapisan permukaan material [3]. Roda gigi yang mengalami kontak fatigue akan mengalami kerusakan pertama kali biasanya terjadi didaerah dedendum dan terjadi pada roda gigi yang paling kecil dari susunan roda gigi [4]. Kerusakan akibat kontak fatigue pada gigi dari roda gigi biasanya terjadi pada satu dari tiga daerah ini yaitu: sepanjang pitch line, pada addendum dan pada dedendum [5]. Pembentukan lubang pada permukaan gigi akan menghasilkan konsentrasi tegangan yang mengakibatkan daerah tersebut mulai terjadi retak dan akhirnya terjadi kegagalan

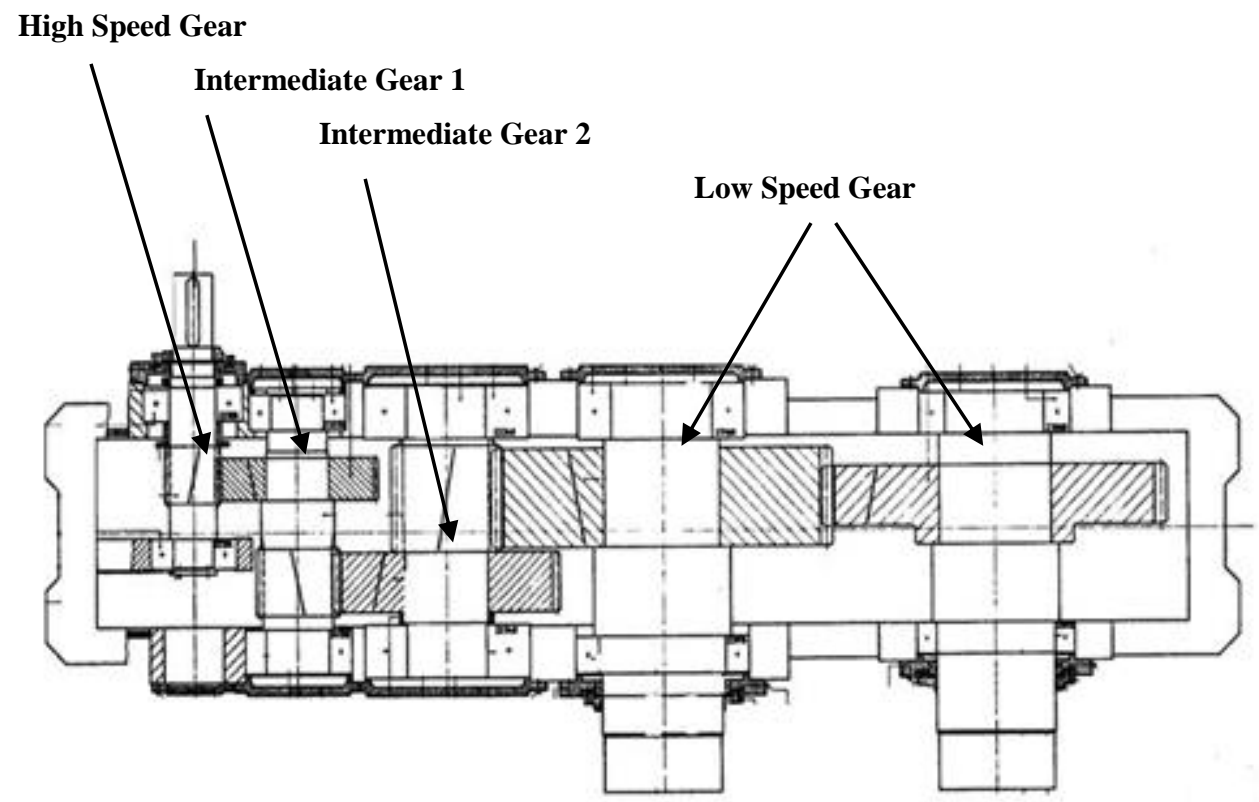

Gambar 1. Susunan roda gigi pada gear box 
[6]. Pitting pada kondisi rolling murni dapat terjadi bahkan dibawah pelumasan yang sudah tepat sekalipun, karena minyak pelumas yang bertindak sebagai cairan yang tidak dapat dimampatkan, sehingga tidak dapat mengalir ke daerah kontak yang dibebani [7].

Pada tulisan ini akan dilakukan analisis untuk melihat akar penyebab kegagalan dari roda gigi intermediate gear 2. Untuk mengetahui akar penyebab kegagalan pada roda gigi intermediate gear 2 ini, dilakukan beberapa langkah yaitu: analisis gaya-gaya yang bekerja pada roda gigi baik analisis gaya statik dan analisis gaya dinamik. Dari analisis gaya ini akan dilakukan analisis tegangan baik secara analitik dengan metode Niemann dan persamaan Lewis maupun dengan metode finite element menggunakan software komersil. Untuk menganalisis penyebab kerusakan roda gigi intermediate gear 2 ini dilakukan dengan pendekatan dengan cara mengamati bentuk patahan yang terjadi dan analisis bentuk kegagalan pada permukaan gigi dari roda gigi tersebut, dengan pendekatan teori kontak mekanik.

\section{KAJIAN PUSTAKA}

\subsection{Roda gigi miring}

Roda gigi miring mempunyai keunggulan yaitu: putarannnya lebih halus dan putaran poros tidak melebihi $3600 \mathrm{rpm}$. Sistem transmisinya lebih ringkas dan kemampuan menerima beban lebih tinggi serta faktor terjadinya slip sangat kecil. Analisis tegangan pada roda gigi dapat dilakukan dengan menggunakan dua pendekatan: metode Niemann dan dengan menggunakan persamaan Lewis.

a. Metoda Niemann

Metoda Niemann yang telah distandarkan oleh DIN dijadikan sebagai acuan dalam memahami dasar-dasar dalam menentukan tegangan pada akar kaki gigi [11]. Besarnya tegangan yang bekerja pada akar kaki gigi dinyatakan dengan intensitas beban nominal (B). Untuk mendapatkan Intensitas beban nominal (B) dapat ditentukan dengan menggunakan persamaan-persamaan di bawah ini:

a. Daya masukan, $\mathrm{N}_{1}(\mathrm{HP})$ dan putaran roda gigi $1, \mathrm{n}_{1}(\mathrm{rpm})$

b. Kecepatan keliling, $\mathrm{v}(\mathrm{m} / \mathrm{s})=\frac{\pi n 1 d 1}{60000}$

c. Momen puntir, $\mathrm{M}_{1}(\mathrm{kgf} . \mathrm{m})=716 \mathrm{~N}_{1} / \mathrm{n}(2)$

d. Gaya keliling, $\mathrm{U}(\mathrm{kgf})=2 \mathrm{M}_{1} 10^{3} / \mathrm{d}_{\mathrm{b} 1}$

e. Gaya keliling per lebar gigi,

$$
\mathrm{u}(\mathrm{kgf} / \mathrm{mm})=\mathrm{U} / \mathrm{b}
$$

f. Intensitas beban nominal,

$$
\mathrm{B}\left(\mathrm{kgf} / \mathrm{mm}^{2}\right)=\mathrm{U} /\left(\mathrm{d}_{\mathrm{b} 1} \mathrm{~b}\right)
$$

b. Persamaan Lewis

Dalam mencari daya yang bekerja dalam arah putaran roda gigi ditunjukkan dalam persamaan di bawah ini

$\mathrm{P}(\mathrm{kW})=\frac{T \cdot n}{9.550 .000}$

Dimana daya (P) dalam kW dan kecepatan putaran (n) dalam rpm maka besar torsi dapat dihitung dengan persamaan berikut;

$\mathrm{T}=\frac{P(k W) \cdot 9.550 .000}{n}$

Jika daya $(\mathrm{P})$ dan kecepatan tangensial $\left(\mathrm{v}_{\mathrm{t}}\right)$ diketahui, maka besarnya gaya tangensial dapat dihitung dengan persamaan

$W_{t}=\frac{33.000 . P}{v t}$

Persamaan 9 adalah persamaan Lewis yang mana hanya berlaku pada beban statik dan tidak berlaku pada perhitungan dinamik. Persamaan di bawah ini harus dimodifikasi untuk menghitung adanya pengaruh konsentrasi tegangan dan geometri pada roda gigi. Untuk itu persamaan 10 adalah modifikasi dari persamaan Lewis yang direkomendasikan oleh AGMA (American Gear Manufacturing Association) untuk design praktis roda gigi dan menghitung faktor keadaan kondisi yang berbeda. 


$$
\begin{aligned}
& \sigma=\frac{6 W \frac{t^{2}}{4 x}}{b \cdot t^{2}}=\frac{3 W \cdot p_{d}}{2 b p_{d} x}=\frac{W_{t} p_{d}}{b Y} \\
& \sigma_{b}=\frac{W_{t} p_{d}}{F J} \frac{K_{a} K_{m}}{K_{v}} K_{s} K_{b} K_{l}
\end{aligned}
$$

Dimana:

$\mathrm{Wt}=$ Beban tangensial yang diteruskan

$\mathrm{Ka}=$ Faktor aplikasi

$\mathrm{Kv}=$ Faktor dinamik

$\mathrm{Ks}=$ Faktor ukuran

$\mathrm{Kl}=$ Faktor idler (1.42 jika rancangan idle gear)

$\mathrm{Km}=$ Faktor distribusi beban

$\mathrm{Kb}=$ Faktor rim thickness

$\mathrm{Pd}=$ Diameter pitch

$\mathrm{F} \quad=$ Lebar gigi

$\mathrm{J}=$ Faktor geometri untuk kekuatan bending

\subsection{Keausan Lelah}

Keausan ini terjadi akibat interaksi permukaan dimana permukaan yang mengalami beban berulang akan mengarah pada pembentukan retak mikro. Retak mikro tersebut pada akhirnya menyatu dan menghasilkan pengelupasan material [3]. Tingkat keausan sangat bergantung pada tingkat pembebanan. Gambar 2 memberikan skema mekanisme keausan lelah tersebut.

\subsection{Kontak Mekanik}

Seperti pada semua komponen mekanik pada umumnya, roda gigi juga mengalami keausan dikarenakan adanya kontak mekanik. Secara umum area kontak antara roda gigi memiliki bentuk segiempat (rectangular) dan bisa dikelompokkan dalam kontak garis (line contact). Kontak yang terjadi pada roda gigi berupa kontak non-conformal dan termasuk dalam deformasi elastis. Kontak nonconformal dan deformasi elastis dikategorikan dalam line contact Elastohydrodynamic Lubrication (EHL) [10].

Pada kenyataannya, permukaan roda gigi tidaklah halus. Kontak sebenarnya yang terjadi adalah antara asperity pada permukaan roda gigi. Tekanan kontak dan beban kontak mempunyai peranan penting pada koefisien gesek dan daya yang hilang. Kontak pada roda gigi ditunjukkan pada Gambar 3.
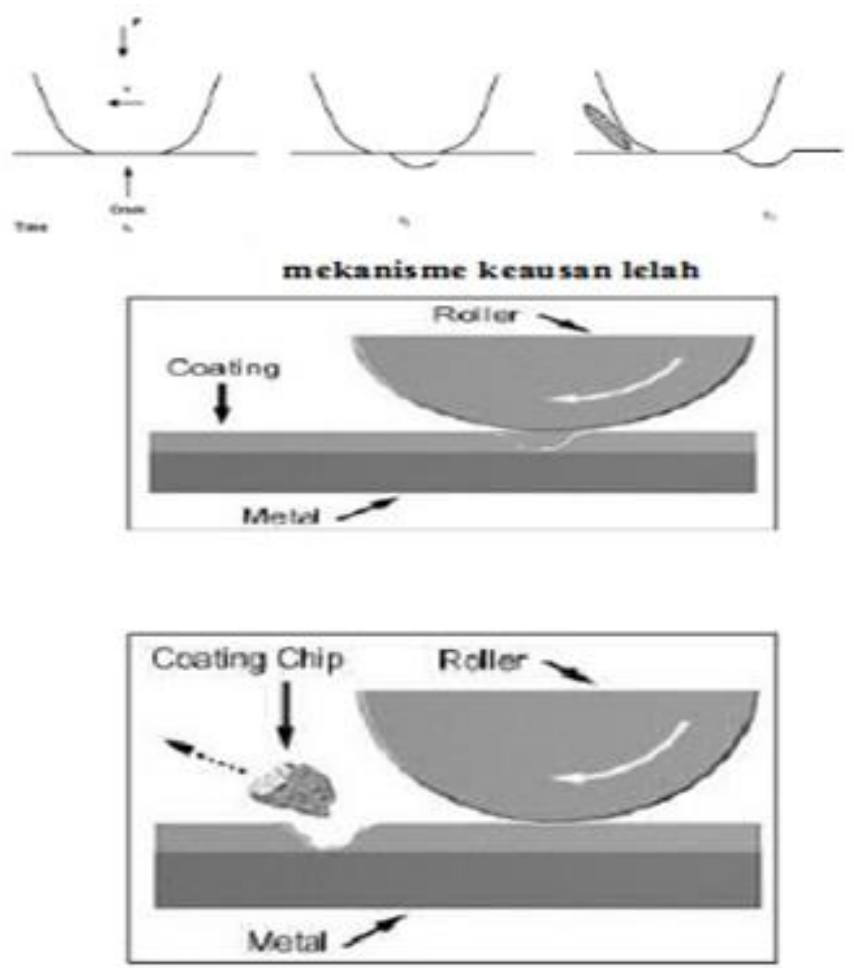

Gambar 2. Mekanisme keausan lelah [9] 
Berdasarkan teori Hertz dari kontak elastik, jika dua permukaan saling berkontak maka akan terbentuk point atau line kontak seperti Gambar 4.

Lebar kontak dapat dinyatakan dengan

$a=\sqrt{\frac{2 F}{\pi L} \frac{\left(1-v_{1}^{2}\right) / E_{1}+\left(1-v_{2}^{2}\right) / E_{2}}{1 / d_{1}+1 / d_{2}}}$

Tekanan maksimum dapat dinyatakan dengan

$P_{\text {maks }}=\frac{2 F}{\pi a L}$

Dimana $\mathrm{d}_{1} \mathrm{dan}_{\mathrm{d}}$ adalah diameter pitch dari pinion dan gear. Sehingga besarnya tekanan maksimum (Hertzian Stress) dapat dinyakan dengan:

$P_{\text {maks }}=\sigma_{H}=0,564 \sqrt{\frac{F\left(\frac{1}{R_{1}}+\frac{1}{R_{2}}\right)}{\frac{1-v_{1}^{2}}{E_{1}}+\frac{1-v_{2}^{2}}{E_{2}}}}$

\section{METODOLOGI}

\subsection{Prosedur Penelitian}

Gambar 5 memperlihatkan tahapan untuk menyusun langkah-langkah yang akan dilakukan dalam analisis kegagalan pada roda gigi miring. Pada tulisan ini, ada beberapa tahapan yang akan dilakukan dalam analisis kegagalan pada roda gigi, yaitu: menetukan gaya dan tegangan yang bekerja pada roda gigi miring untuk dapat memahami bentuk-bentuk kegagalan yang terjadi pada roda gigi tersebut.Tahap awal adalah studi literatur yang terkait dengan roda gigi miring. Dari hasil studi literatur diperoleh informasi seperti nomenklatur roda gigi, jenis roda gigi, kemudian geometri, gayagaya yang bekerja, dan bentuk-bentuk kegagalan yang terjadi pada roda gigi miring. Tahap kedua dilakukan pengumpulan data mengenai roda gigi miring dengan melakukan pengukuran langsung ke lapangan dan memotret bentuk patahan roda gigi. Data yang akan diperoleh dilapangan dapat dilihat pada Tabel 1.

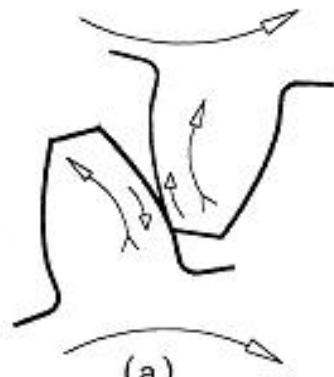

(a)

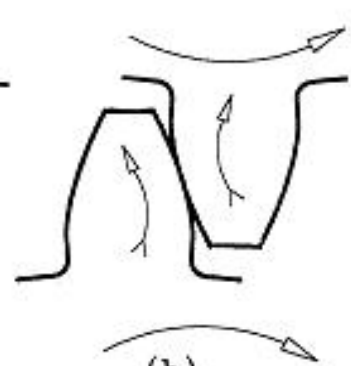

(b)

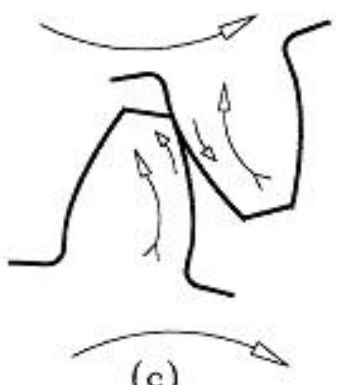

(c)

Gambar 3. Mekanisme kontak roda gigi, (a) pada titik pertama kontak, (b) pada titik pitch dan (c) pada titik terakhir kontak [10]

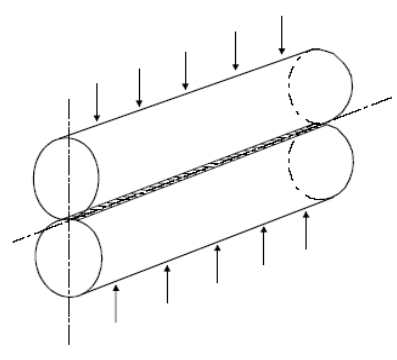

(a)

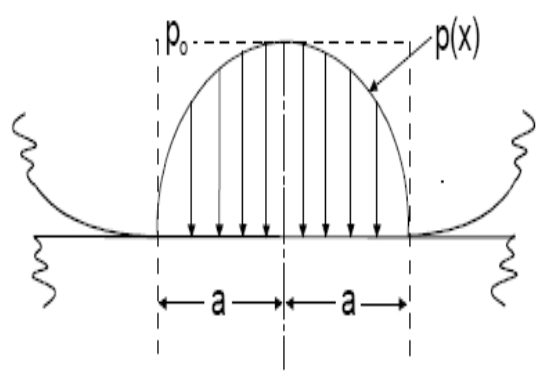

(b)

Gambar 4. Kontak antara dua permukaan: (a) line kontak dan (b) distribusi tegangan di daerah kontak [10] 


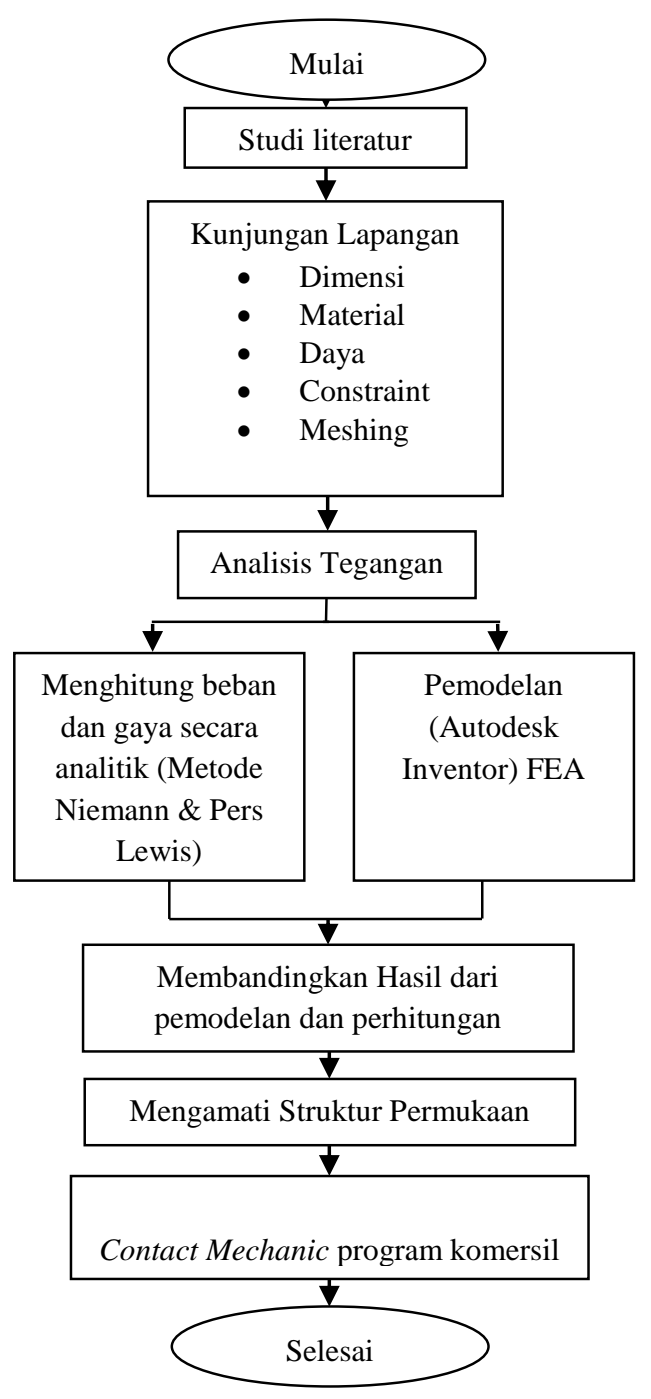

Gambar 5. Flowchart Penelitian

Tabel 1. Nomenklatur dari Pinion Gear dan Intermediate Gear 2 di lapangan

\begin{tabular}{|l|c|l|l|}
\hline Nomenklatur & Simbol & Pinion & Intermediate Gear 2 \\
\hline Daya (Input) & $\mathrm{P}$ & $900 \mathrm{~kW}$ & $900 \mathrm{~kW}$ \\
\hline Putaran (Input) & $\mathrm{n}$ & $980 \mathrm{rpm}$ & $980 \mathrm{rpm}$ \\
\hline Daya (Output) & $\mathrm{P}$ & $683 \mathrm{~kW}$ & $683 \mathrm{~kW}$ \\
\hline Putaran (Output) & $\mathrm{n}$ & $299 \mathrm{rpm}$ & $107 \mathrm{rpm}$ \\
\hline Sudut Tekan & $\varphi / \alpha$ & $14^{\circ}$ & $14^{\circ}$ \\
\hline Helix angle & $\beta$ & $20^{\circ}$ & $20^{\circ}$ \\
\hline Diameter lingkaran jarak bagi & $\mathrm{d} 0$ & $226 \mathrm{~mm}$ & $685 \mathrm{~mm}$ \\
\hline Lebar gigi & $\mathrm{F} / \mathrm{b}$ & $255,5 \mathrm{~mm}$ & $255,5 \mathrm{~mm}$ \\
\hline Diameter lingkaran kepala & $\mathrm{dk}$ & $246 \mathrm{~mm}$ & $705,6 \mathrm{~mm}$ \\
\hline Diameter lingkaran kaki & $\mathrm{df}$ & $206 \mathrm{~mm}$ & $665,6 \mathrm{~mm}$ \\
\hline Jumlah gigi & $\mathrm{N} / \mathrm{z}$ & 23 & 68 \\
\hline Modul & $\mathrm{m}$ & 10,69 & 10,37 \\
\hline Pitch & $\mathrm{p}$ & 33,56 & 32,56 \\
\hline
\end{tabular}




\subsection{Menghitung Gaya dan Tegangan Beban Dinamik Secara Analitik}

\subsubsection{Analisis Roda Gigi Menggunakan Perhitungan Niemann}

Dalam analisis roda gigi miring intermediate gear 2 ini menggunakan perhitungan berdasarkan standar DIN [11]. Ada beberapa langkah yang akan digunakan untuk menganalisis kegagalan roda gigi miring, yaitu:

1. Dimensi

2. Intensitas beban nominal

3. Kesalahan gigi (f)

4. Rasio kontak efektif $\left(\varepsilon_{\mathrm{w}}\right)$

5. Faktor tegangan kaki gigi $\left(\mathrm{q}_{\mathrm{w}}\right)$

6. Faktor beban $\mathrm{C}_{\mathrm{S}}, \mathrm{C}_{\mathrm{D}}, \mathrm{C}_{\mathrm{T}}$ dan $\mathrm{C}_{\beta}$

7. Intensitas beban effektif $\mathrm{B}_{\mathrm{w}}$

8. Tegangan effektif kaki gigi $\sigma_{\mathrm{w}}$

9. Tekanan kontak permukaan gigi $\mathrm{k}_{\mathrm{w}}$

10. Tahanan scoring permukaan gigi $\mathrm{k}_{\mathrm{F}}$

11. Faktor keamanan terhadap patah lelah kaki gigi $\mathrm{S}_{\mathrm{B}}$

12. Faktor keamanan terhadap kegagalan pitting $\mathrm{S}_{\mathrm{G}}$

13. Faktor keamanan terhadap scoring $\mathrm{S}_{\mathrm{F}}$

\subsubsection{Menghitung Tegangan dengan Menggunakan Persamaan Lewis}

Dari persamaan 7 diperoleh besarnya torsi yang bekerja pada roda gigi sebesar 60.749 N.m dan pada roda gigi miring terdapat 3 jenis beban yang bekerja secara bersamaan yaitu beban tangensial (Wt), beban aksial (Wx), dan beban radial (Wr).

$\mathrm{Wt}=177.370 \mathrm{~N}$,

$\mathrm{Wx}=44.223,3 \mathrm{~N}$, dan

$\mathrm{Wr}=64.557,5 \mathrm{~N}$

Dengan menggunakan persamaan Lewis (persamaan 10) akan diperoleh tegangan pada roda gigi, sebesar $\sigma_{b}=324,48 \mathrm{MPa}$.

\subsection{Pemodelan Dengan Menggunakan Program Komersil Autodesk inventor}

\subsubsection{Pemodelan dengan batang kantilever} Untuk memberi beban, maka dipilih gaya dengan ikon force, pilih sisi yang menghadap keatas pada bagian gear seperti terlihat pada Gambar 6 .

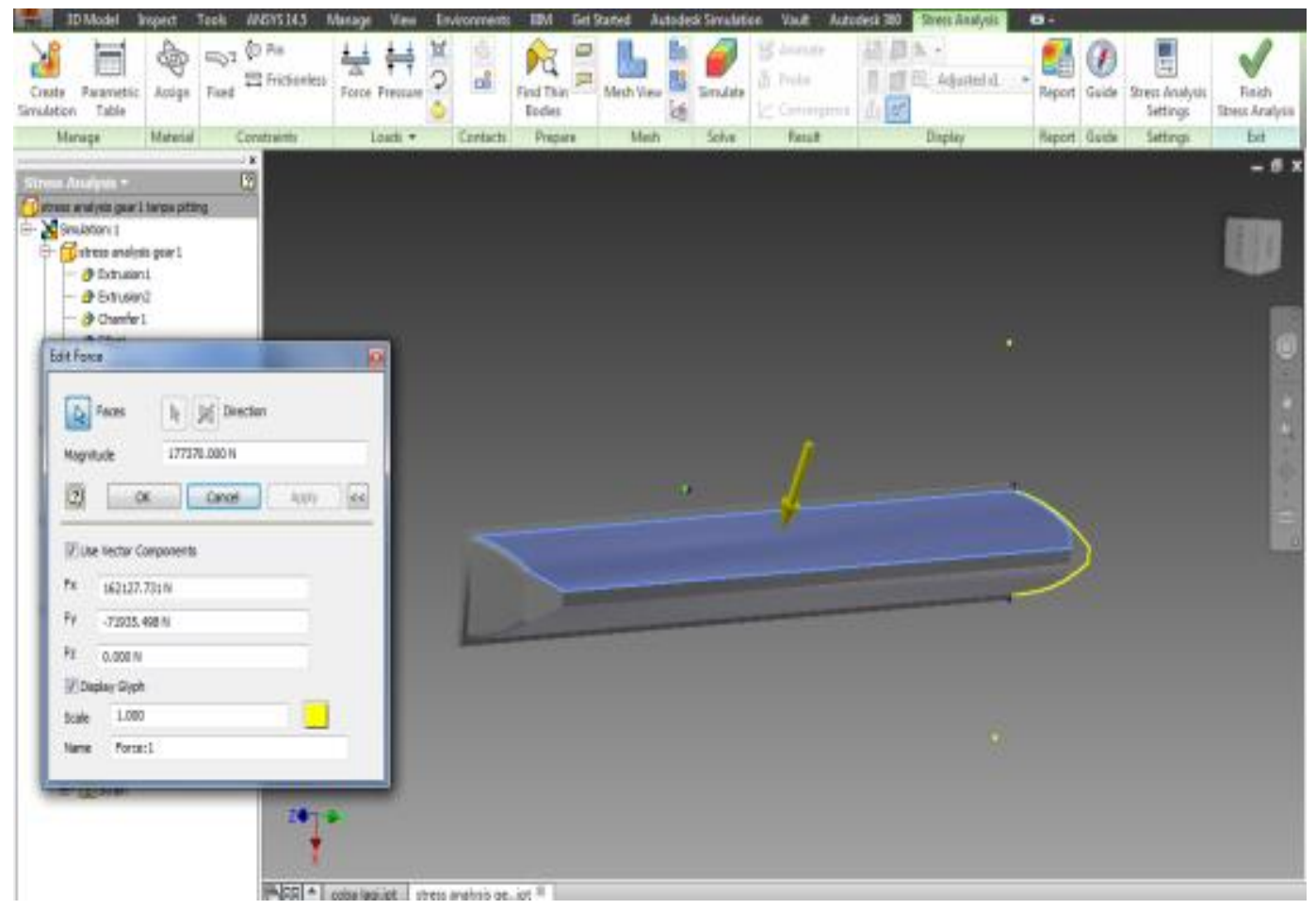

Gambar 6. Memberikan gaya (force) pada gear face 


\subsubsection{Pemodelan roda gigi secara keseluruhan} Dalam pemodelan roda gigi secara keseluruhan dengan menggunakan Autodesk simulation mechanical ini ditunjukkan pada Gambar 7.

\subsection{Mencari Nilai Besarnya Tegangan Pada Permukaan Yang Terdapat Pitting dengan Pemodelan Inventor}

Pemodelan inventor dengan cara memberikan bentuk pitting sebagai pusat distribusi tegangan yang bekerja apabila diberi gaya. Pemodelan adanya pitting ditunjukkan pada Gambar 8 .

Setelah mendapatkan nilai gaya dari metode Niemann, persamaan Lewis, dan pemodelan FEA maka akan dibandingkan dengan yield strength spesimen roda gigi yang komposisinya telah didapat dan diukur berapa nilai yield strength dari kandungan $\mathrm{Fe}, \mathrm{C}, \mathrm{Si}, \mathrm{Mn}$ dan $\mathrm{Cr}$ pada spesimen. Kemudian nilai yield strength inilah yang akan dibandingkan dengan hasil pendekatan melalui metode Niemann, persamaan Lewis dan FEA.

\subsection{Tegangan yang Terjadi Pada Permukaan kontak Roda Gigi}

Tegangan kontak pada permukaan roda gigi Intermediate Gear 2 diperoleh dengan cara pendekatan kontak mekanik. Persamaan Hertzian stress digunakan untuk menentukan tegangan Hertzian dan tegangan geser pada sub-surface. Disamping itu dilakukan perhitungan kontak stress dan shear stress dengan pendekatan elemen hingga dengan software komersil.

\section{HASIL DAN PEMBAHASAN}

\subsection{Fakta Lapangan}

Gear box jenis Jahnel-Kesterman beroperasi normal dengan daya sekitar 683-900 kW. Motor penggerak mempunyai daya $900 \mathrm{~kW}$. Oli yang digunakan adalah Masri FLG ISO VG 320 yang telah diganti secara berkala sesuai rokemandasi manufacturer. Beberapa gigi dari roda gigi failure pada intermediate gear 2. Gambar 9 memperlihatkan kegagalan dari roda gigi intermediate gear 2 .

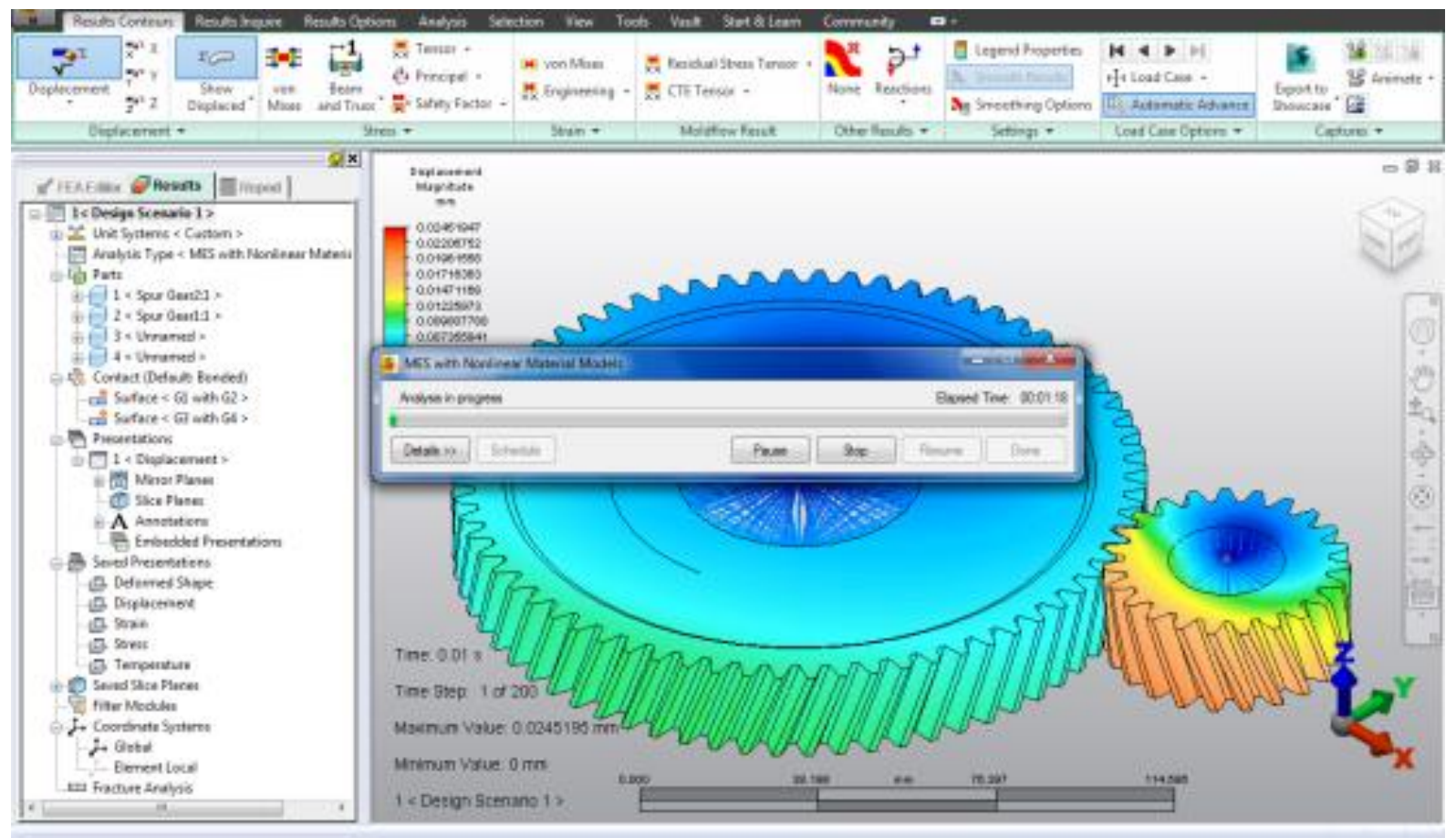

Gambar 7. Hasil Pemodelan Inventor 


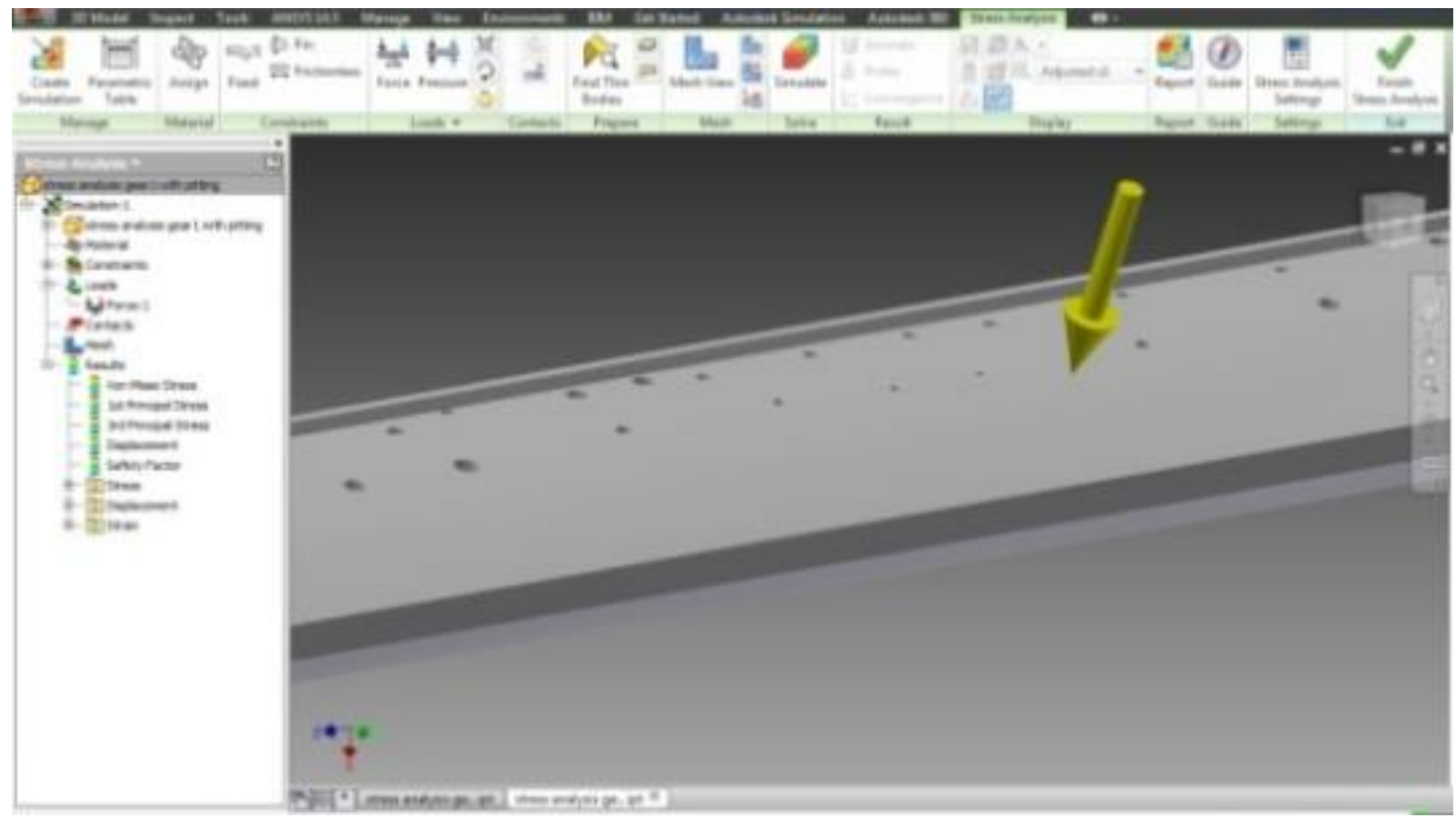

Gambar 8. Batang kantilever dengan adanya pitting pada permukaan roda gigi
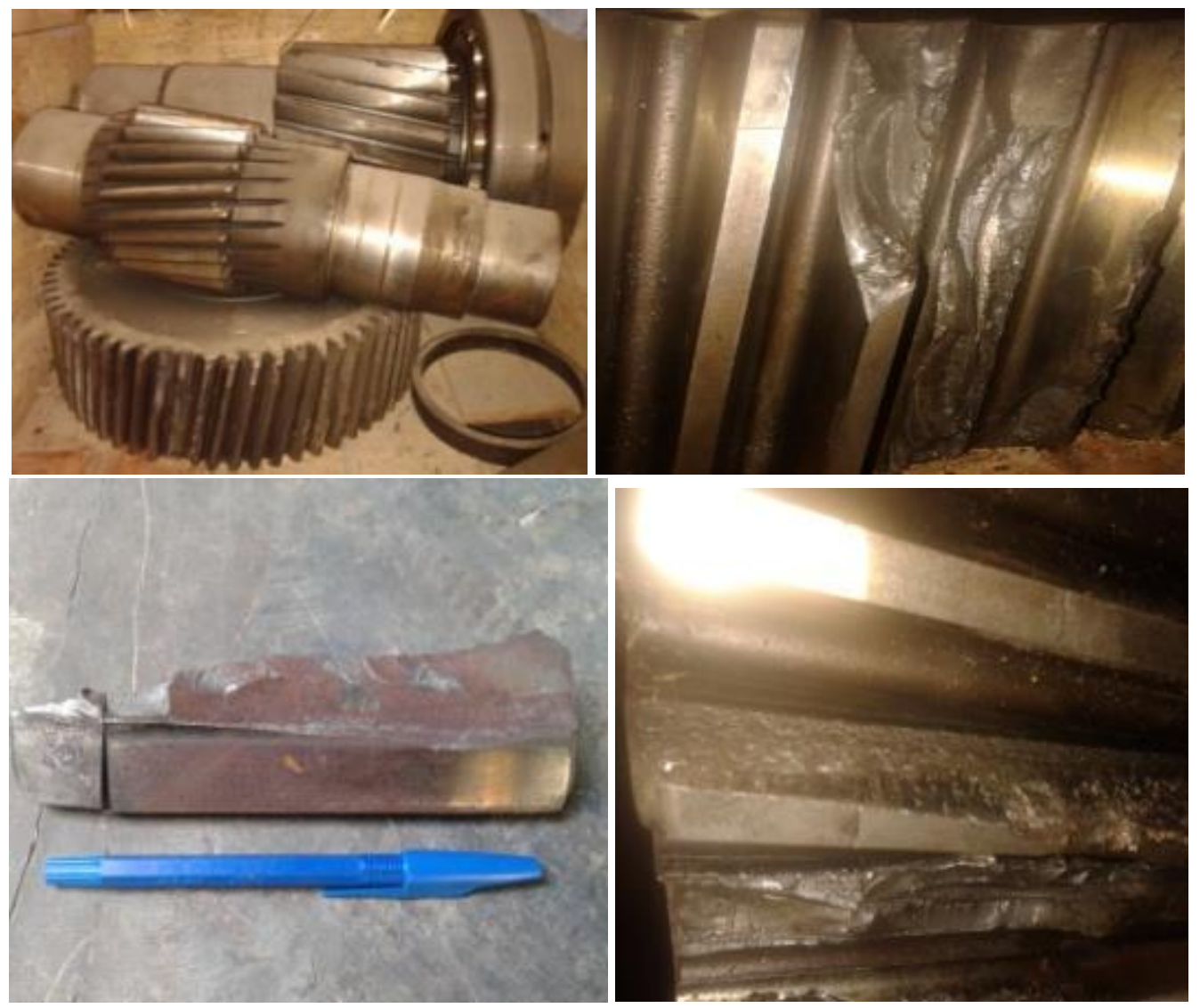

Gambar 9. Intermediate Gear 2 dan Pinion Gear 


\subsection{Pengamatan Secara Visual Bentuk Kegagalan Roda Gigi}

Pada gambar 10 terlihat bahwa adanya scuffing (scoring) pada permukaan gigi, penyebab terjadinya scuffing adalah adanya pelumasan yang kurang baik. Disamping itu, pada permukaan roda gigi terlihat adanya lubang-lubang kecil yang disebut dengan pitting. Pada gigi yang patah dijumpai 2 (dua) bentuk patahan, yaitu berupa patahan lelah (Gambar 11a) dan patahan ulet (Gambar 11b).

\subsection{Gaya-gaya Pada Roda gigi}

Dengan menggunakan prinsip aturan tangan kanan, maka dapat dilihat arah torsi pada susunan roda gigi pada gear box seperti diperlihatkan pada Gambar 12. Besarnya torsi pada masing-masing roda gigi dapat dilihat pada Tabel 2.

Tabel 2. Nilai Torsi Pada Roda Gigi

\begin{tabular}{|c|c|c|c|}
\hline No & Poros & Putaran (rpm) & Torsi (Nm) \\
\hline \hline 1 & A & 980 & $6.655,76$ \\
\hline 2 & B & 298.98 & 21.816 \\
\hline 3 & C & $\mathbf{1 0 7 . 3 7}$ & $\mathbf{6 0 . 7 4 8}$ \\
\hline 4 & D & 35.36 & $184.446,8$ \\
\hline 5 & E & 35.36 & $184.446,8$ \\
\hline
\end{tabular}

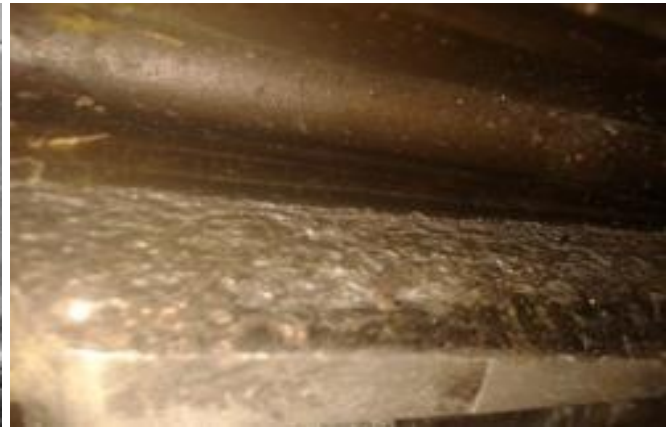

Gambar 10. Kegagalan scuffing dan pitting pada permukaan gear

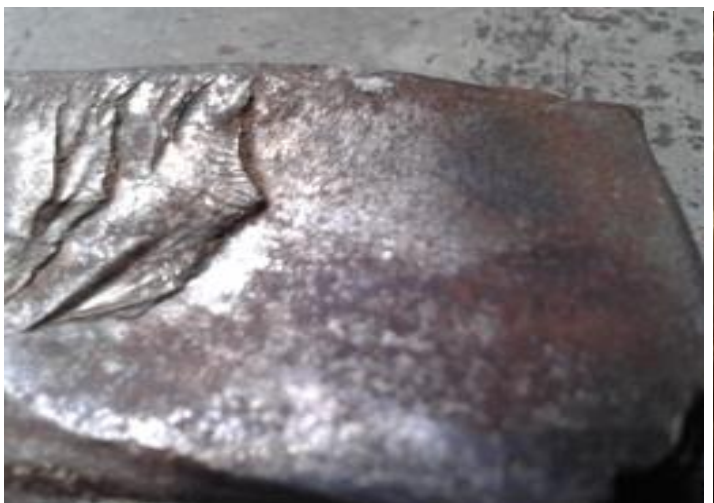

(a)

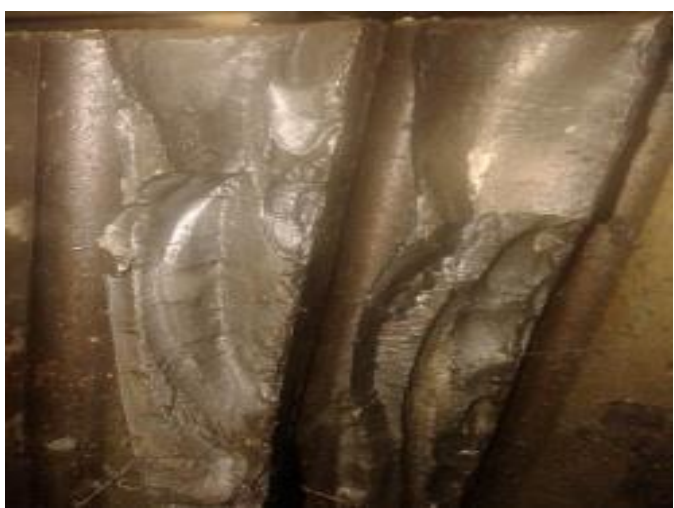

(b)

Gambar 11. Bentuk patah lelah spesimen intermediate gear 2 
4.4. Perbandingan Tegangan yang Terjadi padaPermukaan Gigi antara Perhitungan Niemann, Lewis dan FEA (Finite Element Analysis)

Dari hasil pengujian terhadap material dari roda gigi dengan menggunakan EDX (Tabel 4) diperoleh komposisi karbon sebesar $0,60 \%$, mangan sebesar $0,69 \%$, chromium sebesar $1,7 \%$ dan nikel sebesar $1,4 \%$ maka material dari roda gigi ini termasuk pada low alloy steel dengan nilai yield strength-nya sebesar $1860 \mathrm{MPa}$ [5]. Dari data tegangan yang bekerja pada permukaan kaki gigi (Tabel 3) memperlihatkan bahwa tegangan tersebut berada di bawah kekuatan material dari roda gigi intermediate gigi 2 (1860 MPa). Dari fakta ini jelas bahwa kegagalan dari roda gigi intermediate gear 2 tersebut, bukan karena beban statik namun diakibatkan oleh beban dinamik atau fatigue.

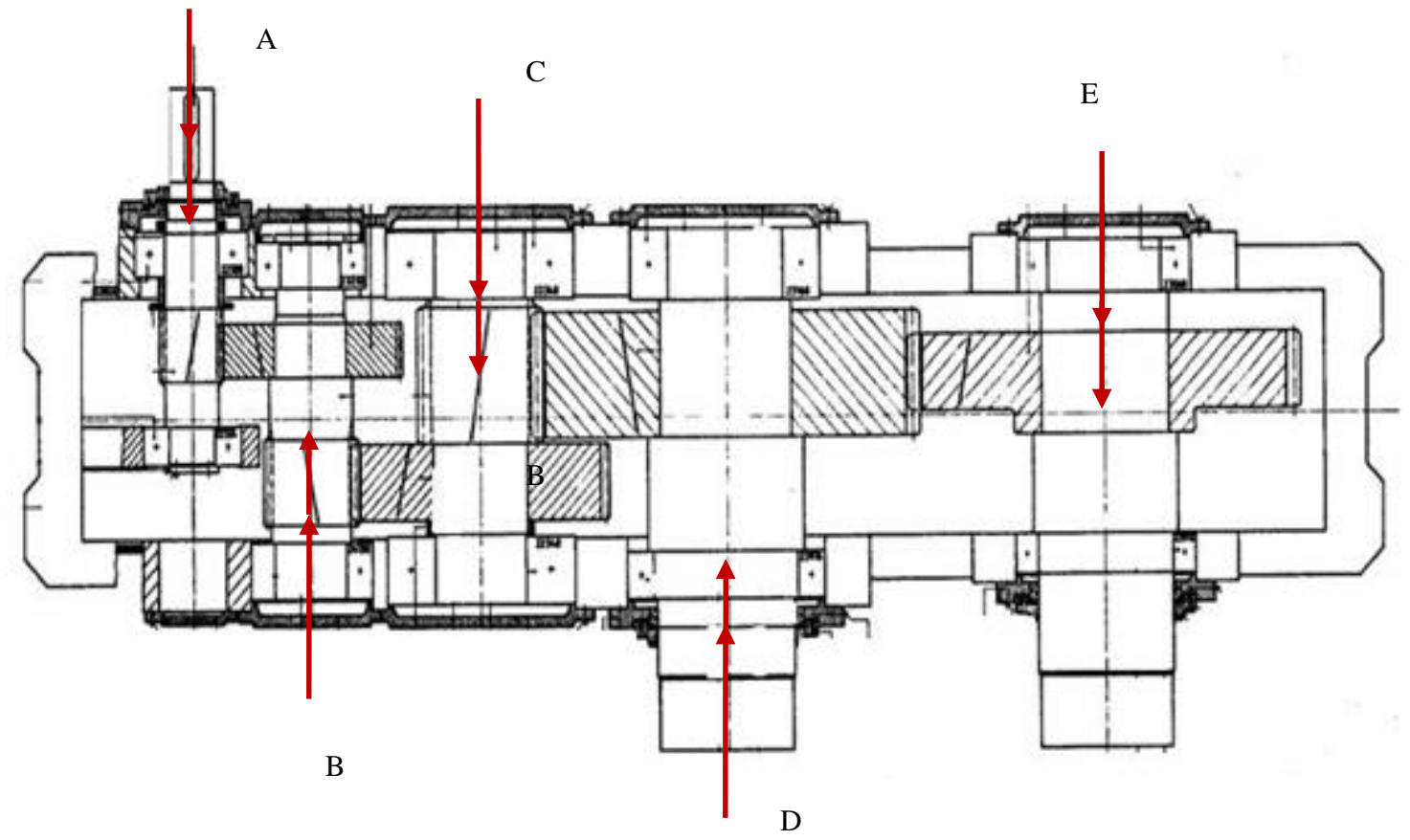

Gambar 12. Susunan roda gigi pada Gear box

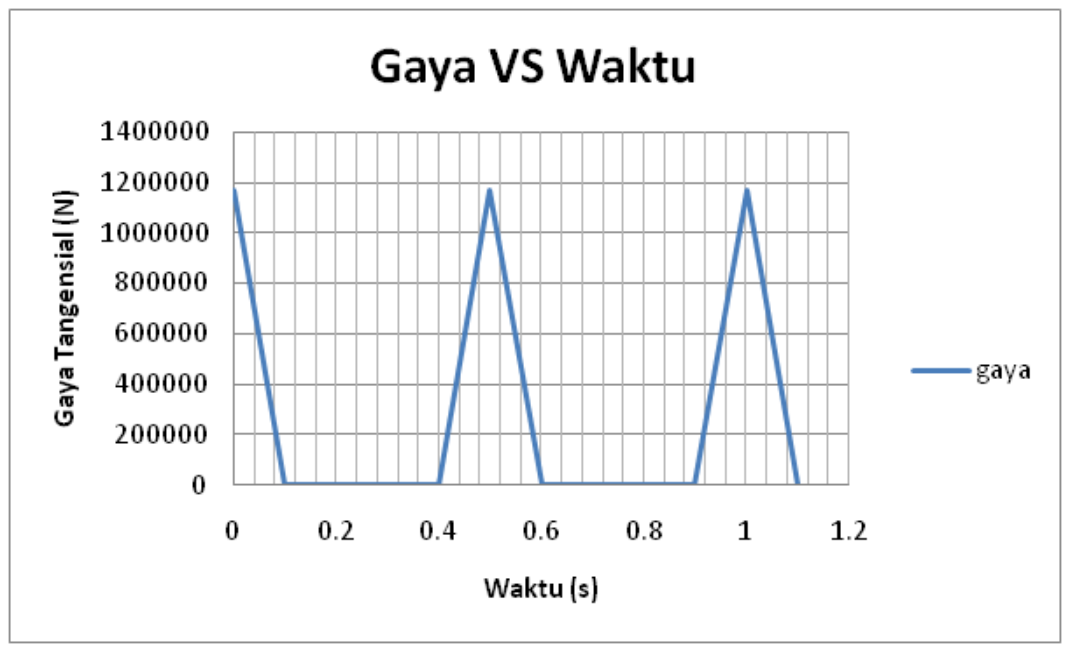

Gambar 13. Susunan roda gigi pada Gear box 


\subsection{Kontak mekanik}

Besarnya tekanan kontak berdasarkan Hertzian Stress diperoleh sebesar 541,56 MPa dan besarnya tegangan geser maksimum sebesar 164,63 MPa. Dimana tegangan geser maksimum ini terjadi pada sub-surface dari permukaan gigi. Hasil analisis numerik untuk tegangan kontak yang terjadi pada permukaan gigi dengan menggunakan program software komersil dapat dilihat pada Gambar 14 dan 15.

Tabel 3. Perbandingan tegangan yang bekerja pada kaki gigi akibat beban dinamik dan beban statik

\begin{tabular}{|c|c|c|c|c|}
\hline \multicolumn{2}{|c|}{ Beban Dinamik } & \multicolumn{2}{c|}{ Beban Statik } \\
\hline \multirow{2}{*}{ Metode Niemann } & Persamaan Lewis & \multicolumn{2}{|c|}{ Batang Kantilever } & \multirow{2}{*}{ Kontak berpasangan } \\
\cline { 3 - 4 } & & Tanpa Pitting & Dengan Pitting & \\
\hline $352 \mathrm{MPa}$ & $324,48 \mathrm{MPa}$ & $120,7 \mathrm{MPa}$ & $182,5 \mathrm{MPa}$ & $434,3 \mathrm{MPa}$ \\
\hline
\end{tabular}

Tabel 4. Komposisi material roda gigi

\begin{tabular}{|c|c|c|c|}
\hline Element & Burn 1 & Burn 2 & Burn 3 \\
\hline $\mathrm{Fe} \%$ & 94,7 & 94,9 & 95,0 \\
\hline $\mathrm{C} \%$ & 0,861 & 0,673 & 0,535 \\
\hline $\mathrm{Si} \%$ & 0,367 & 0,296 & 0,223 \\
\hline $\mathrm{Mn} \%$ & 0,698 & 0,589 & 0,550 \\
\hline $\mathrm{P} \%$ & 0,0167 & 0,0141 & 0,0151 \\
\hline $\mathrm{S} \%$ & 0,0144 & 0,0133 & 0,0111 \\
\hline $\mathrm{Cr} \%$ & 1,77 & 1,65 & 1,65 \\
\hline
\end{tabular}

(a)

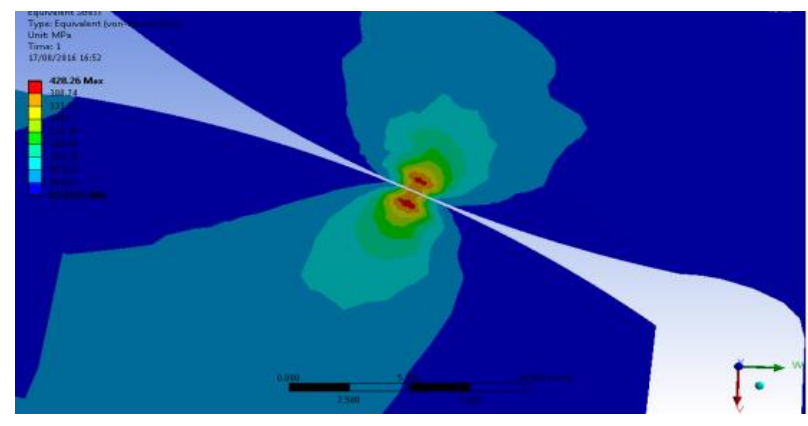

(b)

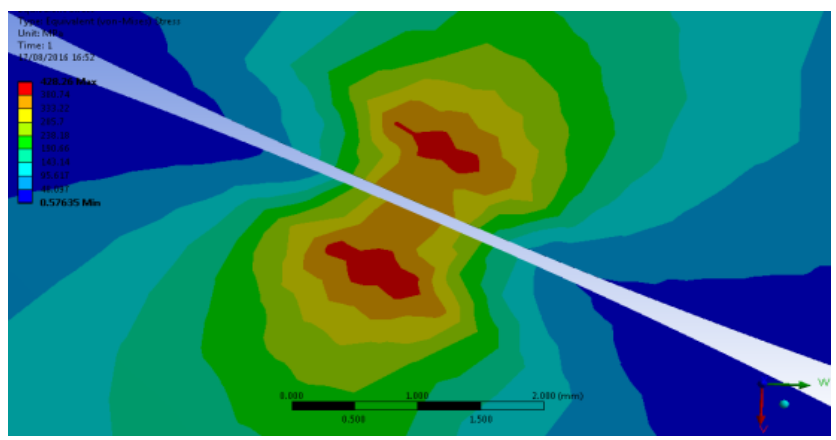

Gambar 14. Distribusi tegangan (Von Misses stress); (a) pada permukaan dua buah roda gigi yang berkontak dan (b) perbesaran 
Fenomena pitting ini (Gambar 16) telah menjadi perhatian yang serius terutama pada roda gigi yang mengalami pembebanan yang cukup besar dengan kecepatan putaran yang rendah maupun kecepatan putaran yang tinggi [12]. Awal mula terbentuknya fenomena pitting terjadi micro pitting pada permukaan gigi, yang disebabkan oleh terbentuknya crack (retak) pada sub-surface permukaan roda gigi, sehingga mengakibatkan tegangan geser yang terjadi (Gambar 15) melebihi tegangan geser yang diizinkan dari kekuatan yield material. Pitting yang terbentuk biasanya terjadi pada daerah dedendum. Retak yang terbentuk ini akan merambat ke permukaan gigi yang disebabkan oleh beban berulang yang terjadi pada permukaan gigi, sehingga membentuk lubang yang sangat halus (micro pitting) kemudian berkembang menjadi lubang yang cukup besar (pitting), dalam jangka panjang akan terbentuk lubang yang membesar (splating).

(a)

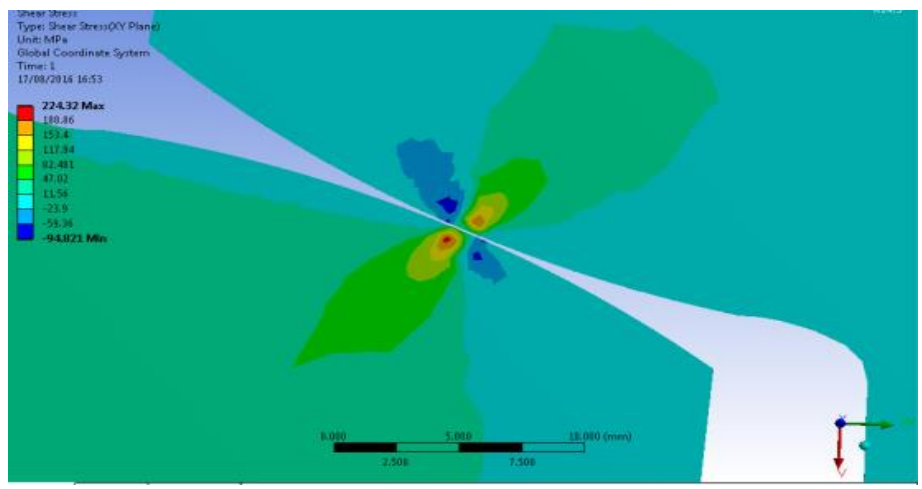

(b)

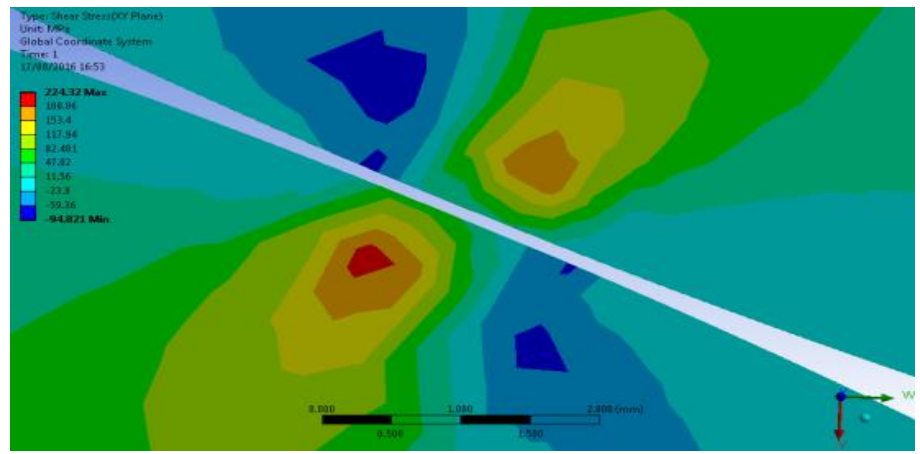

Gambar 15. Distribusi tegangan geser; (a) pada permukaan dua buah roda gigi yang berkontak dan (b) perbesaran

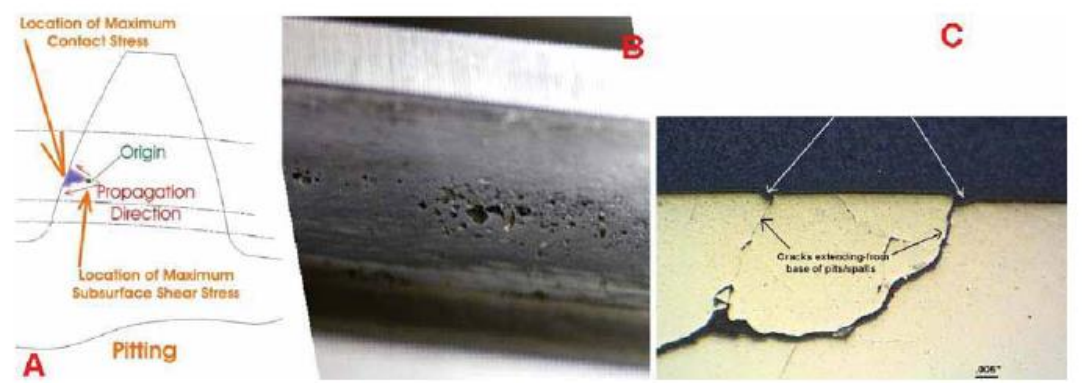

Gambar 16. Fenomena pitting akibat beban dinamik, (a) Mulai terbentuknya crack pada subsurface permukaan gigi, (b) Terbentuknya pitting pada permukaan gigi, dan (c) Perambatan[12]. 
Penyebab terjadinya pitting sampai saat ini belum diketahui secara pasti. Beberapa teori menyatakan bahwa fenomena pitting ini terjadi pada saat running in atau saat roda gigi pertama kali dioperasikan [13]. Teori lain juga mengatakan bahwa pitting juga dapat terjadi karena beban yang bekerja cukup besar dengan lapisan pelumasan yang kurang baik sehingga akan menjadi resiko terbentuknya micro pitting [12].

\section{KESIMPULAN}

Dari analisis kegagalan yang telah dilakukan pada roda gigi miring memperlihatkan bahwa besarnya Gaya tangensial yang terjadi pada roda gigi intermediate gear 2 sebesar 177.370 N. Gaya sebesar itu akan menyebabkan tegangan yang terjadi akar kaki gigi berdasarkan persamaan Lewis sebesar, $\sigma_{\mathrm{b}}=324,48 \mathrm{MPa}$ dan dengan metode Niemann sebesar, $\sigma_{\mathrm{w}}=333 \mathrm{MPa}$. Perhitungan dengan metode finite elemen (FEA) memperlihatkan bahwa tegangan bending yang terjadi pada akar kaki gigi jika dimodelkan tanpa pitting besarnya tegangan sebesar, $\sigma_{b}=120,7 \mathrm{MPa}$, jika dimodelkan adanya pitting besarnya tegangan sebesar, $\sigma_{\mathrm{b}}=182,5 \mathrm{MPa}$, dan jika dimodelkan dengan roda gigi yang berpasangan besarnya tegangan, $\sigma_{\mathrm{d}}=434,3 \mathrm{MPa}$. Sedangkan kekuatan dari material roda gigi dari hasil uji komposisinya menunjukkan bahwa material dari roda gigi adalah low alloy steel dengan nilai yield strength-nya sebesar $1860 \mathrm{MPa}$ dimana kekuatan dari roda gigi masih berada di atas tegangan bending yang bekerja pada akar kaki gigi. Sehingga kegagalan yang terjadi pada roda gigi intermediate 2 ini tidak disebabkan oleh beban statik akan tetapi disebabkan oleh beban secara dinamik atau gagal akibat fatigue.

Berdasarkan analisi kontak mekanik memperlihatkan bahwa Hertzian Stress yang terjadi didaerah kontak adalah sebesar 541,56 MPa dan dengan tegangan geser sebesar 164,63 MPa. Hal ini juga diperkuat dengan analisi elemen hingga (FEA) dengan menggunakan software komersil besarnya tekanan kontaknya (von misses) sebesar 428,26 MPa dan tegangan geser sebesar 224,32 MPa. Ini memperkuat bahwa akar penyebab terjadinya kegagalan pada intermediate gear 2 adalah terjadi pitting dan scufing akibat rolling contact pada permukaan roda gigi yang menyebabkan terjadinya konsentrasi tegangan, yang merupakan sumber dari kegagalan roda gigi dan akan mengakibatkan patah lelah.

\section{DAFTAR PUSTAKA}

[1] N. Samceng dan S. Panya "Failure Analysis of a Helical Gear", Paper presented at The First TSME International Conference Mechanical Engineering, 20-22 Oktober 2010, Ubon Ratchathan, Thailand.

[2] K. L. Alchay dan V. Dwakar, "Metalurgical Analysis of Failed Gear", Engineering Failure Analysis, Vol. 9(3), June 2002, pp: 359-365.

[3] K. L. Johnson, "The Strength of Surfaces in Rolling Contact", Journal Mechanical Engineering Science, Vol. 203 (C3), 1989, pp: 151-163.

[4] D. J. Wupi, “Understand How Components Fail", $2^{\text {nd }}$ edition, ISBN 0-87170-671-8, ASM International, Materials Park, Ohio, 1985.

[5] L. E. Alban, "Systematic Analysis of Gear Failure", $2^{\text {nd }}$ edition ISBN 0-87170-200-2, American Society for Metals, The United States of America, 1985.

[6] P. J. L. Fernandes, "Tooth Bending Fatigue Failure in Gears", Engineering Failure Analysis, Vol 3(3), September 1966, 1996, pp: 219-225.

[7] R. J. Shipley dan W. T. Bader, "Failure of Gears", Vol 11, Failure Analysis and Prevention, ISBN 087170-704-7, ASM International, Materials Park, Ohio, 2002.

[8] Setiyana, "Perancangan Roda Gigi Metoda Niemann". Jurusan Teknik Mesin, Fakultas Teknik, Universitas Diponegoro. 2007.

[9] S. Mardjono, "Fracture Mechanics dan Prediksi Umur Kelelahan", Jurusan Teknik Mesin, ITB.

[10] T. Hidayat, "Fenomena Running-in Roda Gigi Transmisi" Program Studi Teknik Mesin, Universitas Muria Kudus, 2014. 
[11] G. Niemann, "Machine Elements Design and Calculation in Mechanical Engineering". Volume II, Springer-Verlag, 1978.

[12] J. D. Raymond, J. C. Roy dan C. Steve, "The Anatomy of a Micropitting-Induced Tooth Fracture Failure-Its Causation", Initiation, Progression and Prevention, Gear Technology, June 2010

[13] T. I. Fowle, "Gear Lubrication: Relating theory and practice", Shell International Petroleum Co. LTd. London. 